\title{
PATHOLOGY OF EXPERIMENTAL HAEMARTHROSIS
}

BY

\author{
S. ROY AND F. N. GHADIALLY \\ Department of Pathology, University of Sheffield
}

Many authors have reported the changes that occur in synovial membrane in chronic haemarthrosis (Key, 1932; Ghormley and Clegg, 1948; Collins, 1951; De Palma and Cotler, 1956; Rodnan, Brower, Hellstrom, Didisheim and Lewis, 1959), but the early changes which occur in this condition and the mechanism by which blood is removed from the synovial cavity are not well understood.

Key (1929) studied the manner in which blood is removed from the knee of the rabbit after a single injection of blood into the joint cavity. He found that most of the red blood cells escaped by passing between the synovial cells but none was phagocytosed by them.

It seemed to us that a better insight into this problem might be obtained by studying the situation under the electron microscope.

We have therefore studied experimentally produced haemarthrosis in the rabbit using this technique.

\section{Materials and Methods}

Experimental Procedure. - 27 normal rabbits weighing about 2,000 g. were used in this experiment. Blood was collected from one of the ear veins in a bottle containing sequestrene to prevent clotting. About 1 to $1.2 \mathrm{ml}$. of this blood was injected into the right knee joint of the same animal; the left knee served as a control. The whole procedure was conducted under ether anaesthesia and strict aseptic precautions.

Collection of Tissues.-Synovial membranes were collected from the infrapatellar region of both knee joints under ether anaesthesia, which was then prolonged to kill the animal. Two or three animals were killed at each of the following time intervals: 2, 4, 8, 24 hours, and daily up till the 7 th day after injection of blood into the joints.

The synovial tissues obtained as described above were placed on a piece of filter paper and dropped in buffered cold osmium (Palade, 1952). After fixation for $2 \mathrm{hrs}$ at $4^{\circ} \mathrm{C}$., the tissue was cut into thin strips about $1 \mathrm{~mm}$. wide. The synovial membrane with a minimum of subsynovial tissue was dissected off the filter paper leaving behind most of the collagenous and fatty tissue which would have interfered with the cutting of ultrathin sections The synovial tissue was then processed by the method of Glauert (1961) and orientated according to the method of Coulter (1962). Sections were cut with the Porter Blune microtome, mounted on uncoated copper grids, staine\& with lead citrate (Reynolds, 1963), and examined unde the A.E.I. EM 6, using an accelerating voltage of 50 og $75 \mathrm{kV}$.

Another piece of synovium from the same joint of eacto animal was fixed in formalin and processed for light microscopy. Sections were stained with haematoxylio and eosin and Perl's Prussian blue reaction.

\section{Macroscopic Examination \\ Results}

Injected blood could be readily identified in the्ष joint cavity in diminishing amounts up till about the 3 rd day. From the 4th day onwards the joints weres almost entirely free of blood. The blood when found in the joint was always fluid and only occasiong ally one or two small clots could be detected. The synovial membrane was bright pink for the first days of the experiment but became gradually palekू after that period and on the 7th day it looked almos normal.

\section{Light Microscopy}

The changes which occur after a single injection of blood will now be compared with the appearance of the normal s snovium. Fig. 1 shows a section o $\bar{p}$ normal synovium obtained from the control (left?

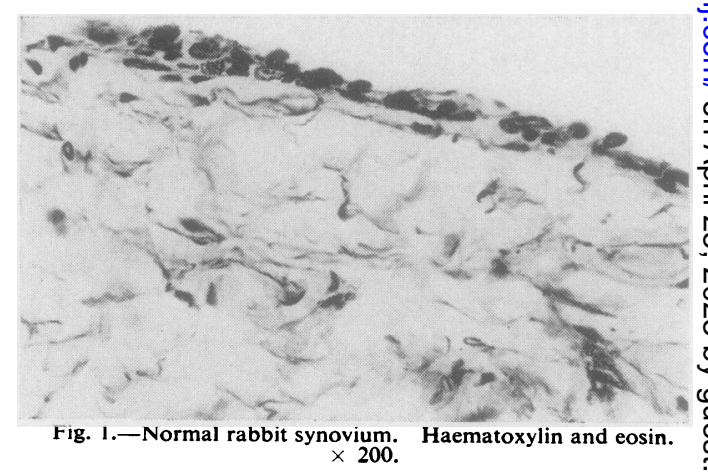


knee of one of the animals. It can be seen that it is composed of one or two layers of flattened synovial cells supported on fibro-fatty tissue. The changes seen after 2, 4, and 8 hrs were essentially similar and will hence be considered together. During this stage the injected red blood cells were seen lying on the surface of the synovium in some places (F:g. 2). At times some red blood cells were also found lying free in the subsynovial tissues or between synovial cells. The synovial cells did not show any gross alteration, but there was an increasing degree of infiltration of

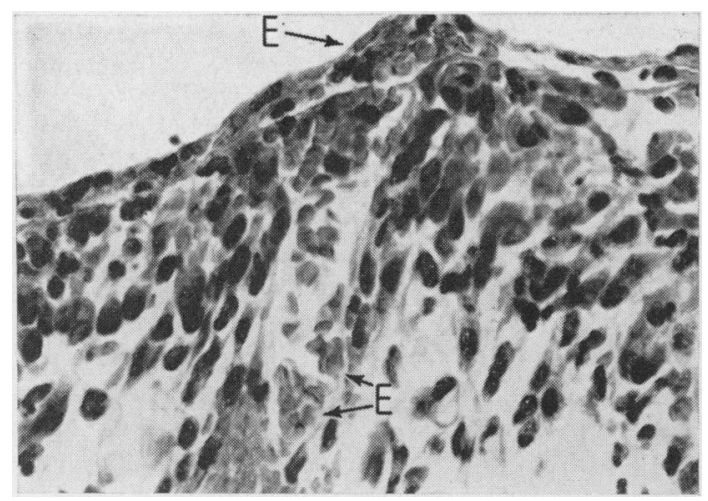

Fig. 2.-A layer of erythrocytes (E) and polymorphs can be seen lying on the surface of the synovium which is infiltrated with many polymorphs. Groups of erythrocytes (E) can also be seen lying free in the synovium and subsynovial tissues. $\times 375$. the synovial and subsynovial tissues with polymorphonuclear leucocytes with advance of time. A search was made in numerous sections for evidence of erythrophagocytosis by synovial cells, but only in rare instances could the occurrence of such a phenomenon be established by this method.

The changes which occur in the synovium 1 to 7 days after the injection of blood show a sequence of events broadly similar to those seen in inflammatory reactions elsewhere. During the first 3 days polymorphonuclear leucocytes preponderate in the inflammatory exudate, and during the latter period many mononuclear cells, lymphocytes, and some plasma cells are seen with only an occasional polymorph. The peak of the inflammatory process was attained by about the 3rd or 4th day and from then on the total number of inflammatory cells seemed to diminish, so that by the 7 th day only a few scattered inflammatory cells could be seen.

An interesting oscurrence was the development of villous, papillary processes in the synovium. The earliest evidence of this was observed in a specimen collected on the 3rd day. Fig. 3 shows a wellformed villous proliferation seen on the 4th day. It will be observed that the subsynovial fat cells in the villi are largely replaced by granulation tissue and that there is also a patchy thickening of the synovium due to an increase in both the size and number of synovial cells. Plaques of such plump synovial cells.

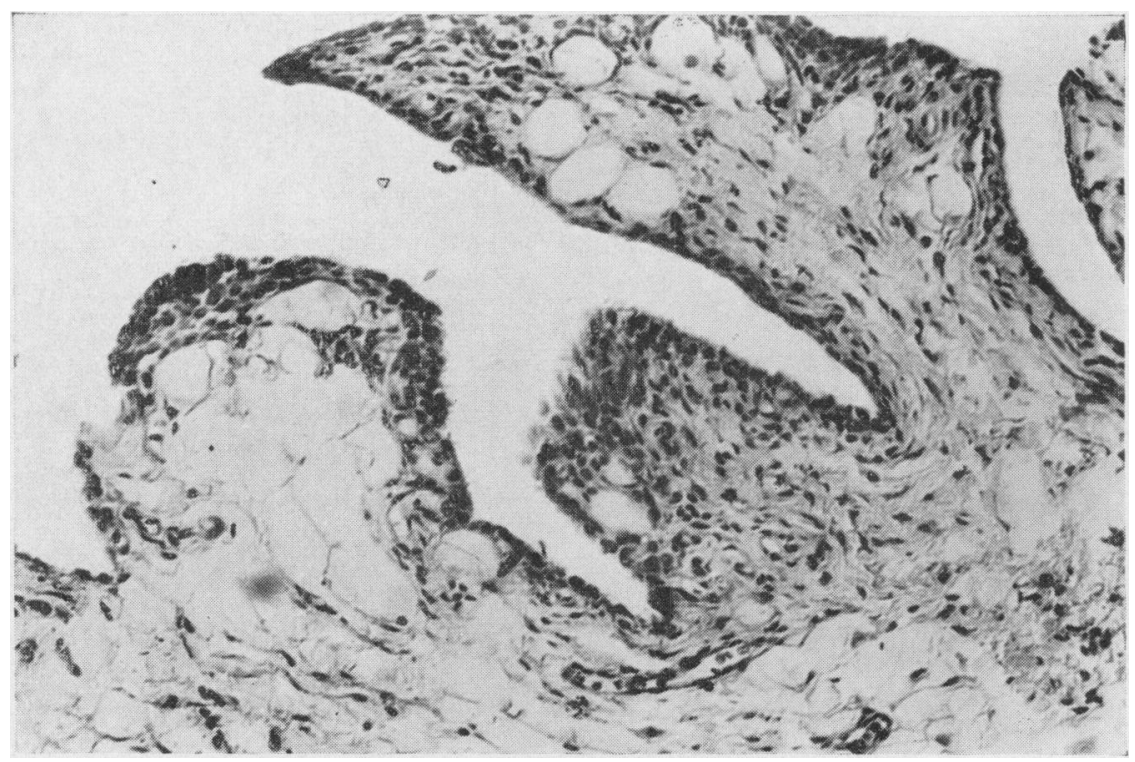

Fig. 3.-Villous proliferation in synovium on 4th day after injection of blood. Haematoxylin and eosin. $\times 125$. 


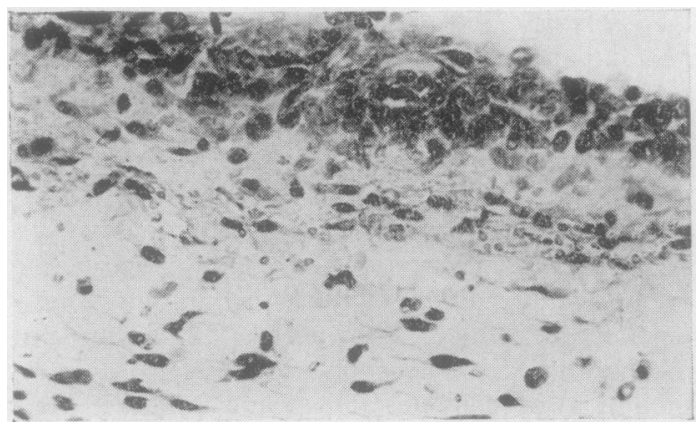

Fig. 4.-Plaque of hypertrophied and hyperplastic synovial cells seen on 3rd day. Haematoxylin and eosin. $\times 200$

were also found in areas where there was no villous change (Fig. 4).

On the 7th day (Fig. 5) villous processes were still seen to persist but in an attenuated form and the synovial and subsynovial tissues were closer to normal in that the cells were less plump and the subsynovial layer mainly fatty.

The Prussian blue reaction for iron was faintly positive on the 2 nd day in occasional synovial cells. On the 3rd day a more clear-cut positive reaction was seen in synovial cells and also in subsynovial macrophages. From then on the reaction became more marked, and many focal accumulations of these cells could still be found on the 7th day.

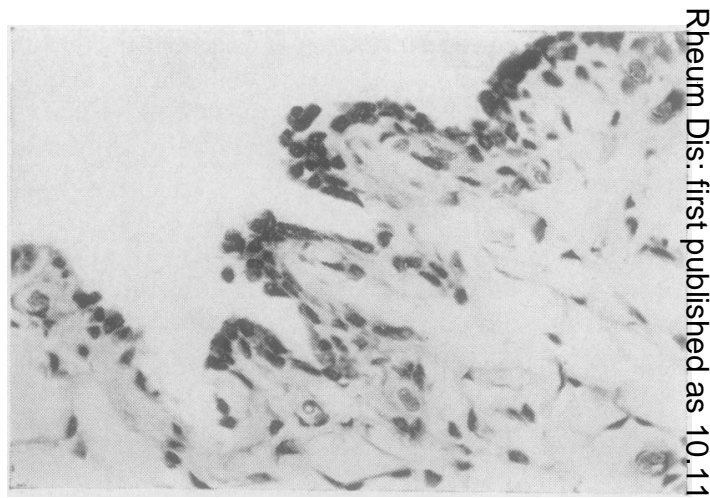
Fig. 5-Synovium on 7th day, showing residual papillary changes $\vec{W}$

\section{Electron Microscopy}

Synovia from the control (left) knees were essener tially similar to the normal rabbit synovium describedr by Ghadially and Roy (1966).

Changes after 2 hrs.-Electron microscopy con을 firmed the light microscopic observation that erythro $-\overrightarrow{-}$ cytes can be found lying on the synovium, between the synovial cells, and in the subsynovial tissues $\frac{0}{\mathrm{C}}$ Even at this early stage some quite clear-cut changes occur in the synovial cells:

(1) Many large filopodia were seen in the surface cells in contrast to the virtual absence of such le filopodia in normal rabbit synovium (Fig. 6).

Fig. 6.-Synovial cell showing well-developed filopodia (F) and some areas of focal cytoplasmic degeneration (F.C.D.). $\times 20,000$.

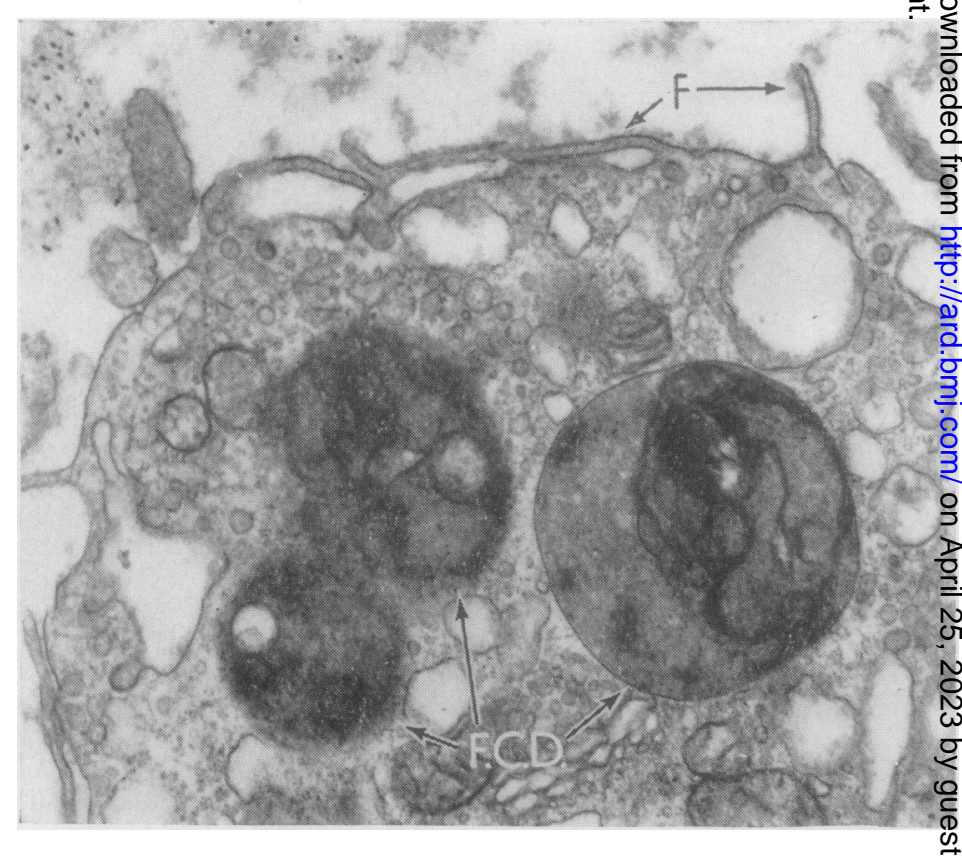


(2) Some of the cells showed a marked dilatation of the cisternae of the endoplasmic reticulum (E.R.) (Fig. 7).

(3) Perhaps the most interesting change was the occurrence of numerous single membrane bound inclusions of variable morphology. Some of these contained membranous formations (Fig. 6), while others contained a flocculent medium density material set in an electron lucent matrix (Fig. 8). The density and structure of the material seen in these bodies was

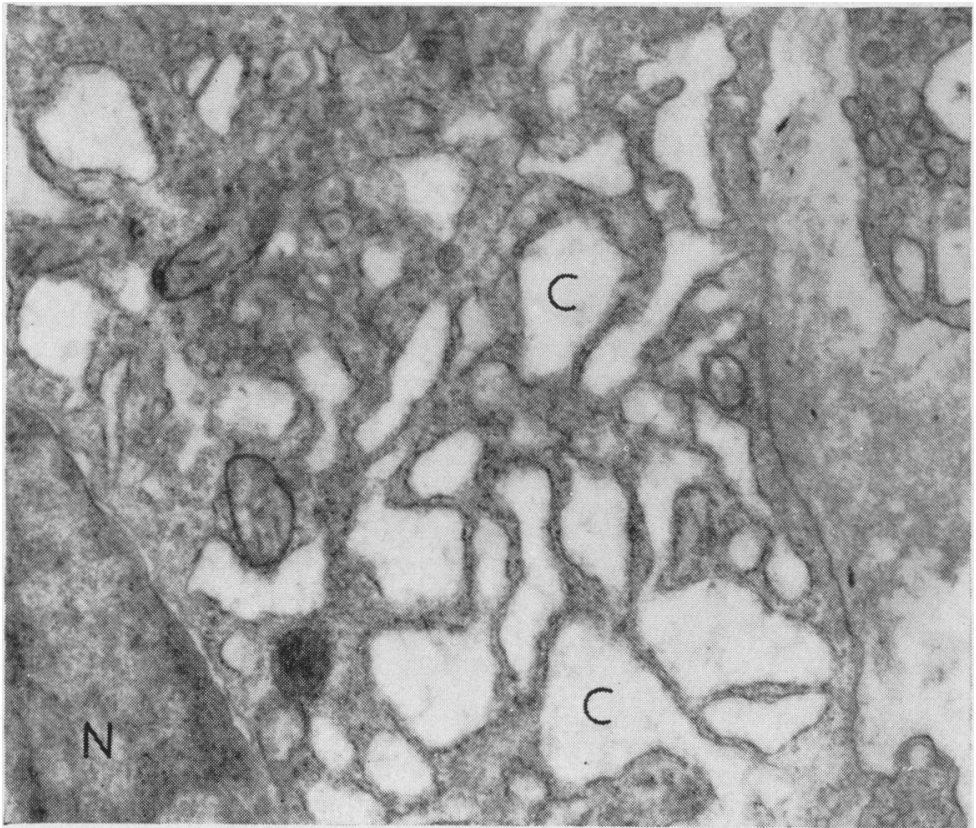

Fig. 7.-Synovial cell, showing dilatation of cisternae (C) of endoplasmic reticulum. Nucleus $(\mathrm{N}) . \times 20,000$

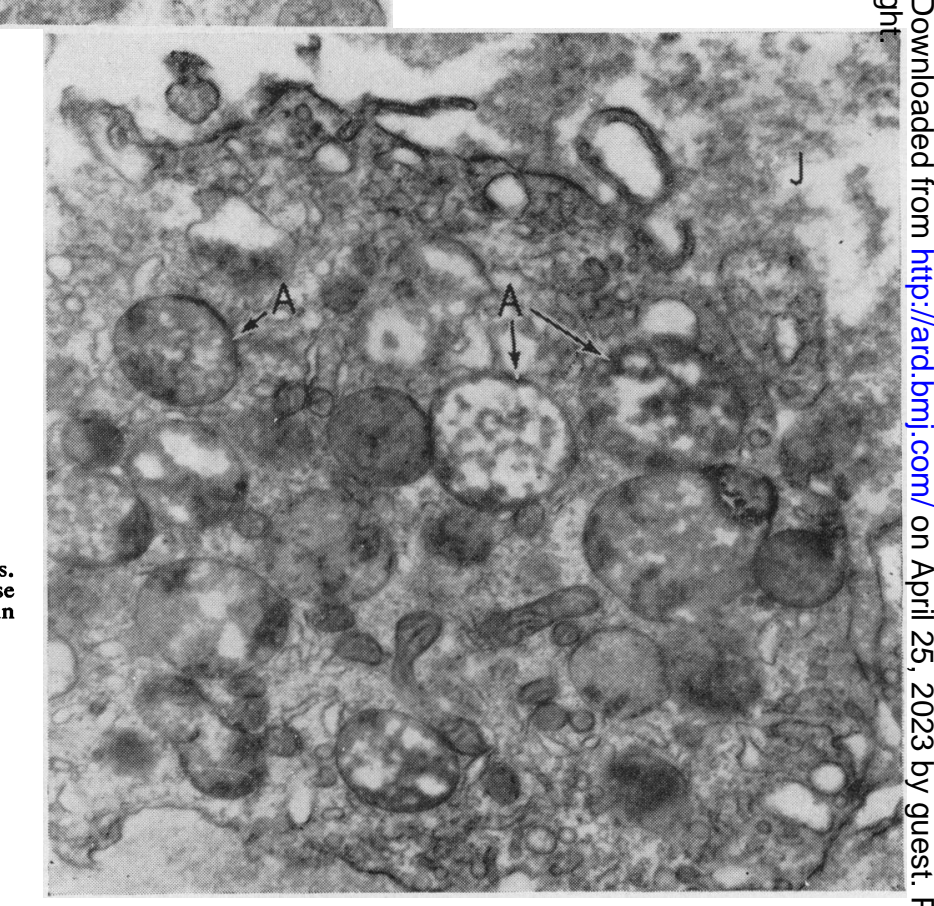

Fig. 8.-Synovial cell containing pleomorphic inclusions The density and structure of the contents of some of these bodies (A) is similar to that of material seen lying in the joint cavity $(\mathrm{J}) . \quad \times 16,000$. 
at times similar to that seen in the joint cavity.

Changes after 4, 8, and 24 hrs.-Electron microscopy confirmed the light microscopic observation that the synovium at this stage is infiltrated by inflammatory cells and also revealed changes in the synovial cells themselves. Single membrane bound pleomorphic inclusions (Figs 6 and 8 ) were seen more frequently than at $2 \mathrm{hrs}$.

An interesting finding was the occurrence of small electron dense particles scattered throughout the $\frac{\bar{\varphi}}{\text {. }}$ cytoplasm of the cell (Fig. 9). Similar particles were $\vec{F}$ also seen in polymorphs infiltrating the synovium? (Fig. 10). This change was first seen in specimens obtained $4 \mathrm{hrs}$ after injection of blood into joint. $\frac{\bar{m}}{\bar{n}}$

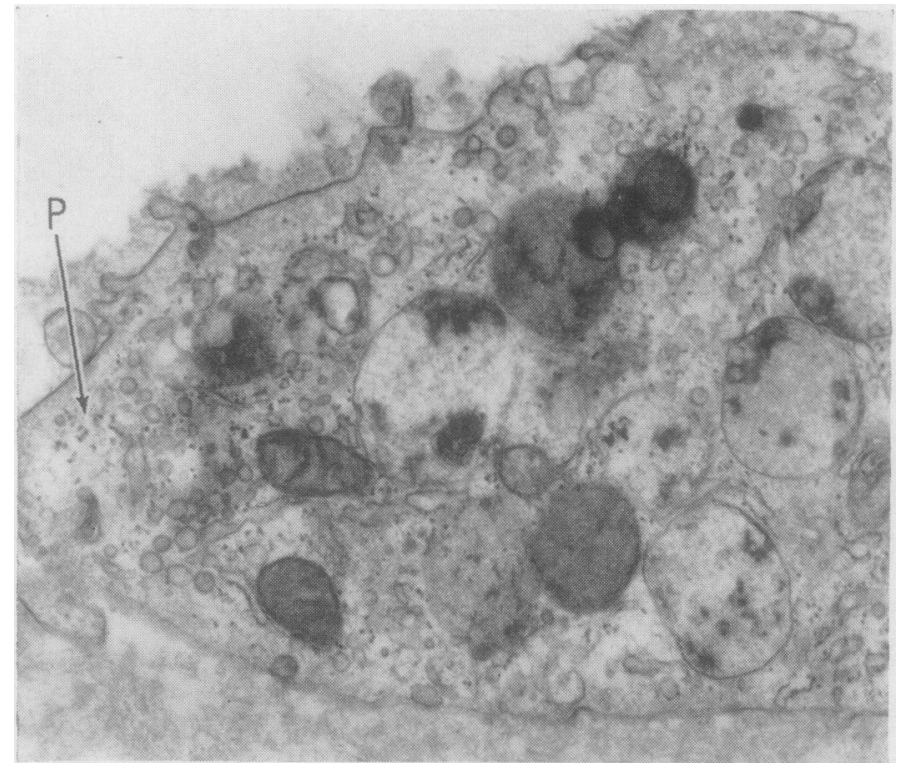

Fig. 9-Synovial cell, showing many elestron dense particles (P) scattered throughout its cytoplasm. $\times 20,000$.

Fig. 10.-Synovial cell (S) and polymorph containing numerous electron dense particles $(P)$ similar to that shown in Fig. 9. $\times 20,500$.

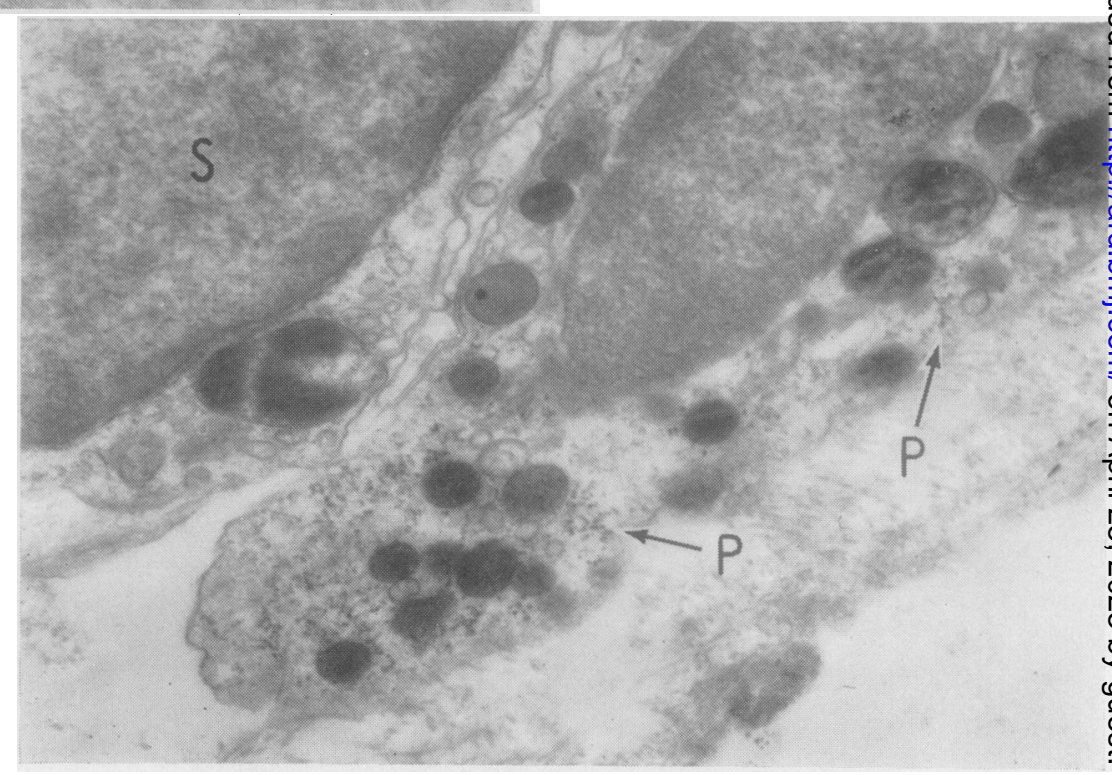




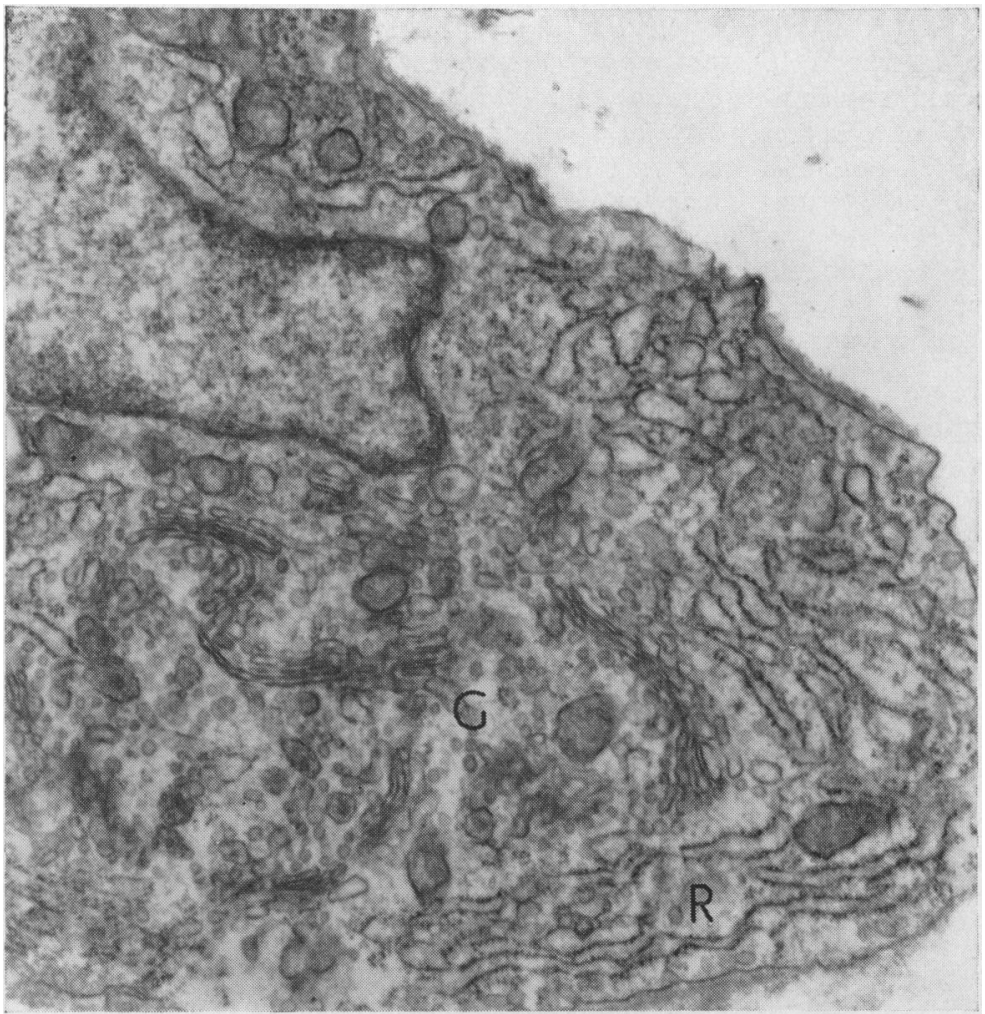

Most of the synovial cells (Fig. 11) showed well-developed complex Golgi systems and also abundant E.R.

They resembled the intermediate cell type described by Roy, Ghadially, and Crane (1966) in human synovium from cases of traumatic effusion.

Fig. 11.- - Intermediate type synovial $O$ systems well-developed. Golging endoplasmic reticulum $(R) . \times 24,000$.

Perhaps the most important finding was erythrophagocytosis by synovial cells. This was first seen at 4 hrs. In Fig. 12, which shows an early example

Fig. 12.- Synovial cell (S) containing two erythrocytes (A and B). Another erythrocyte (C) is seen lying in the joint space (J). A membrane containing a dense body (D) probably of erythrocytic dense body (D) probably of erythrocytic
origin is seen lying near the nucleus $(\mathrm{N})$. $\times 22,500$.

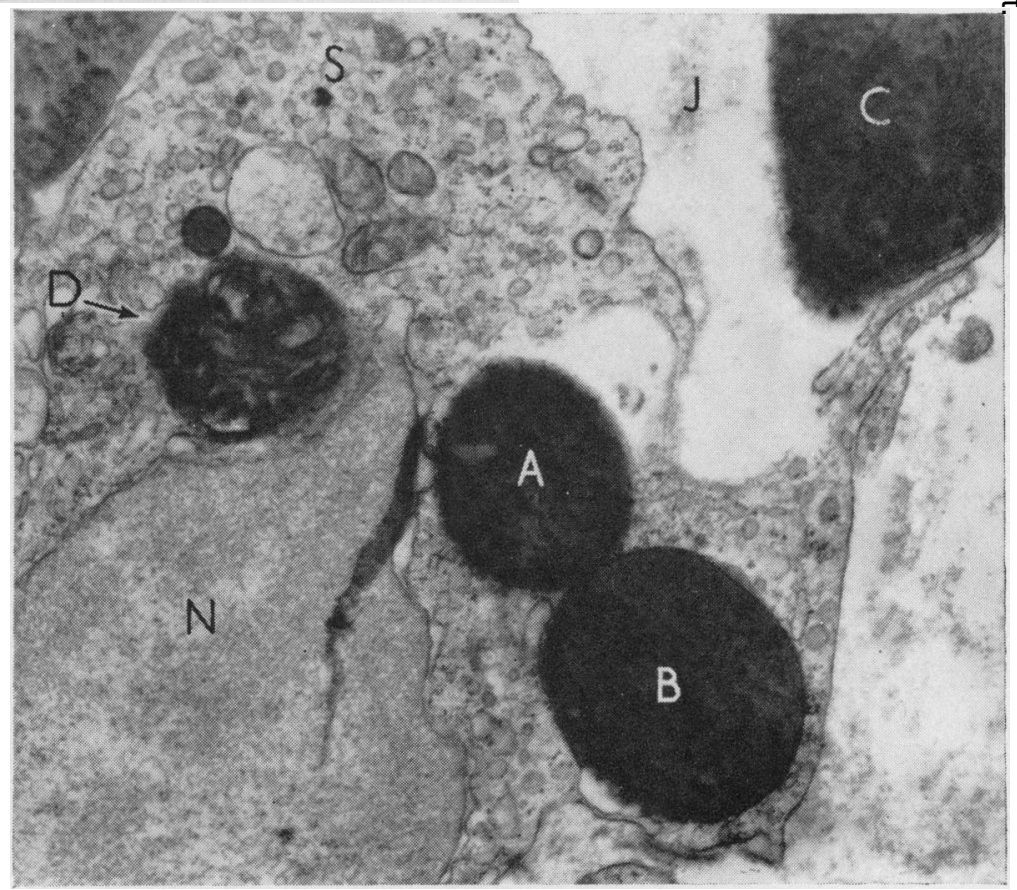


of this process, we see two erythrocytes A and B apparently lying within a Type A synovial cell. Although a two-dimensional view cannot unequivocally establish that these erythrocytes have in fact been incorporated within the synovial cell, this appearance is quite consistent with such an interpretation.

Fig. 13 shows a synovial cell with two filopodia embracing an erythrocyte. This probably indicates the manner in which erythrocytes are incorporated into synovial cells.

Changes after 2 to 7 days.-During this stage there was a diminution in the number of inclusions containing flocculent material and also of membrane containing bodies similar to that described at $2 \mathrm{hrs}$ after injection of blood. Instead of these, new inclusions apparently originating from disintegrating erythrocytes were detected. The fate of the ingested erythrocytes could be traced by studying these inclusions. We shall now show that a primary step in this process is fragmentation of the erythrocyte within the cytoplasm of the phagocytic synovial cell. This seems to be achieved in two ways:

(1) By formation of septa which divide the erythro- cyte. Fig. 14 (opposite) shows an early stage of this process with double walled septa dividing an erythrocyte into three fragments, while Fig. 15 (opposite) on shows a more advanced stage where the erythrocyte is $\Rightarrow$ cut up into three or four major segments and also $\stackrel{\oplus}{\rightarrow}$ many other smaller segments. Further it can be seen ? that other membranous structures have also been developed in its substance.

(2) Fig. 16 (overleaf) shows another way in which fragmentation of the erythrocyte is achieved. Here $\omega$ we see some dense bodies surrounding an erythrocyte $\overrightarrow{0}$ and one arising from it. This picture suggests that fragmentation is achieved by sequestration of small $\omega$ fragments from the surface of the erythrocyte, which are then cast off into the surrounding cytoplasm of $\bar{\partial}$ the phagocytic cell.

The next stage in the process leads to the formation of bodies containing intensely electron opaque concentric membranes and granules. Complex 은 multicentric whorled structures like that shown in Fig. 17 (overleaf) probably represent a further step of $\Phi$ evolution of septally divided erythrocytes similar to $\frac{\mathbb{P}}{\mathrm{O}}$ those shown in Figs 14 and 15, while the small unicen- $\frac{D}{3}$ tric whorled bodies are probably derived from smaller $\underset{\mathbb{\Phi}}{\vec{Q}}$

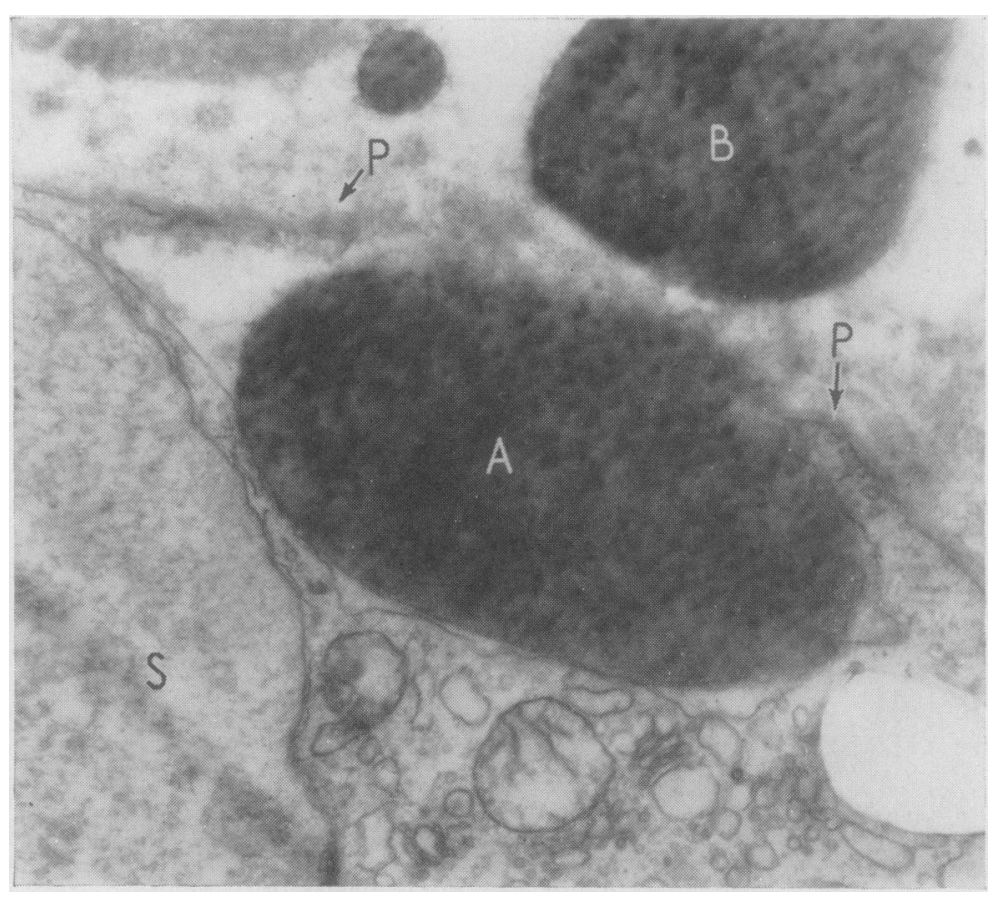

Fig. 13.-Synovial cell (S) with two cytoplasmic processes (P) partially embracing an erythrocyte 
PATHOLOG Y OF EXPERIMENTAL HAEMARTHROSIS

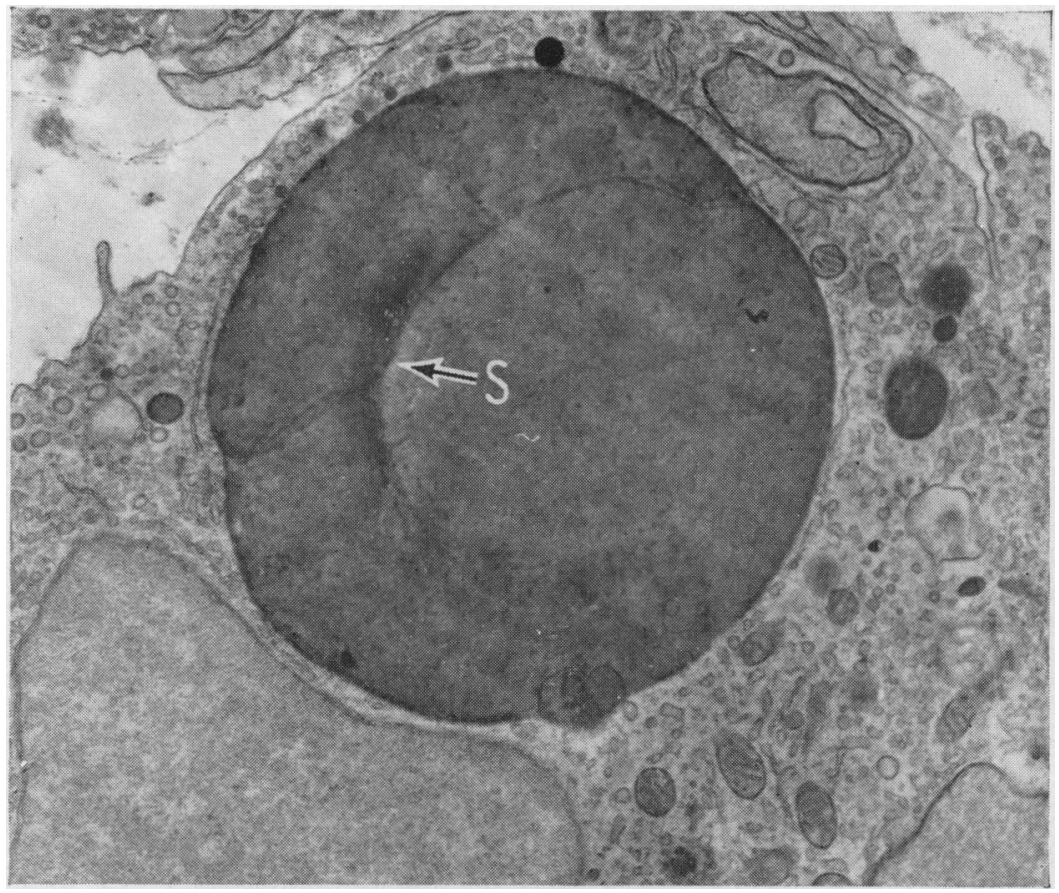

Fig. 14.-Type A synovial cell, showing early segmentation of a phagocytosed erythorocyte by a double-walled tripartate septum $(\mathbf{S}) . \quad \times 10,500$.

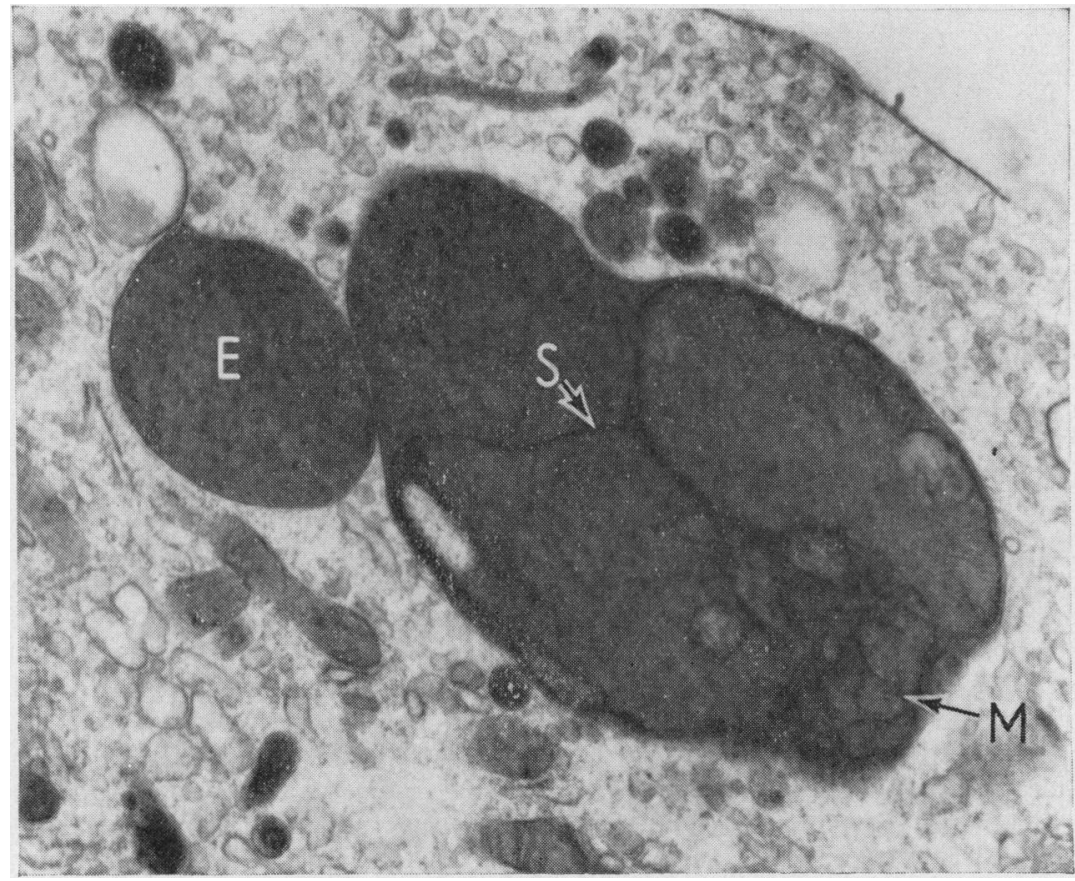

Fig. 15.-A more advanced stage of erythrocyte segmentation. Complex septal formation (S) and other membranous structures (M) are clearly seen. An erythrocyte or erythrocyte fragment (E) is seen adjacent to the segmented erythrocyte. $\times 26,250$. 


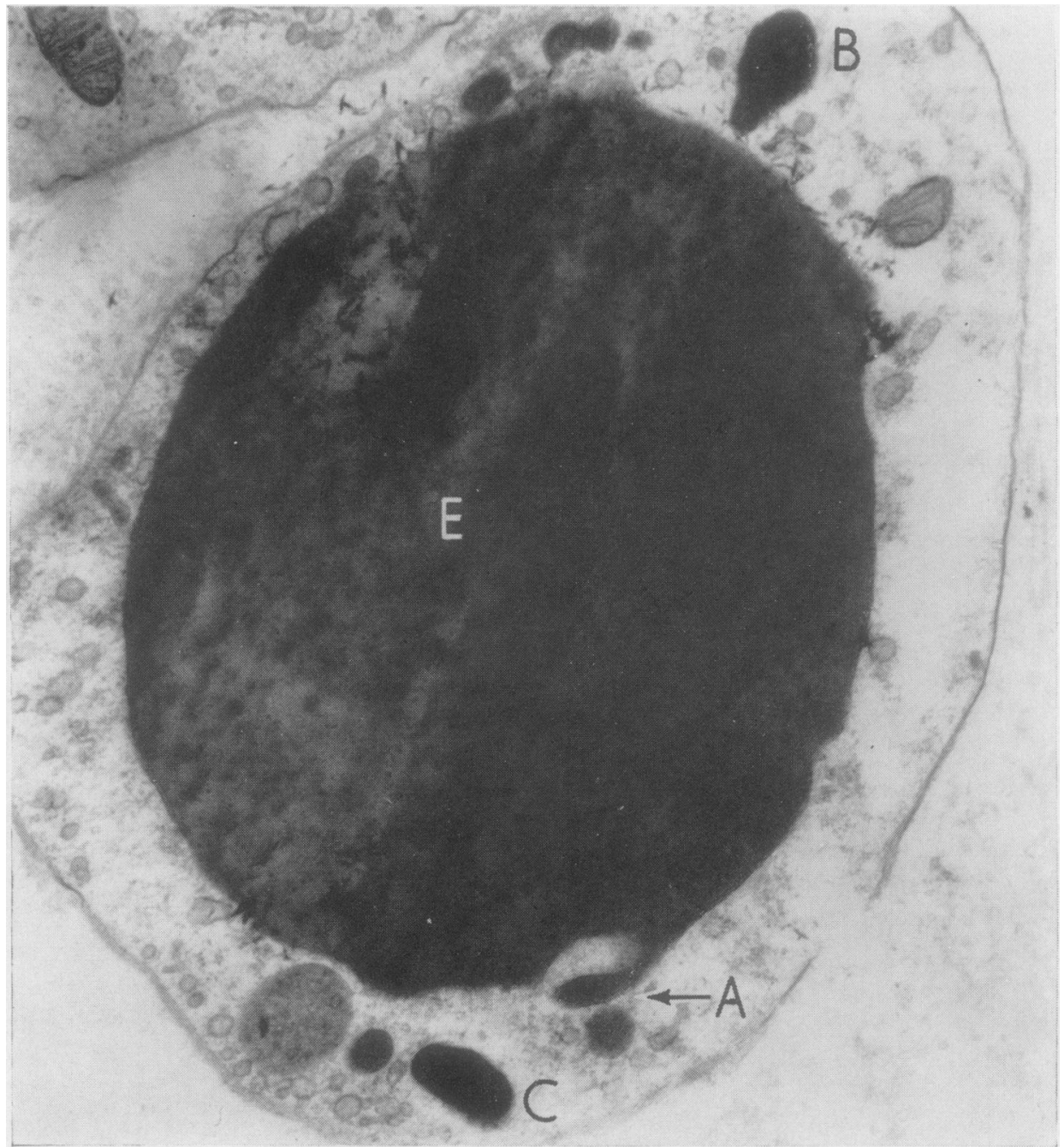

Fig. 16.-Phagocytosed erythrocyte (E) demonstrating the manner in which small fragments are detached off its surface. At one point (A) a small peninsula of erythrocytic substance is seen protruding into the surrounding synovial cell. Other dense bodies (B and $C$ ) probably derived in this manner are seen around the phagocytosed erythrocyte (E). $\times 30,000$.

fragments such as those cast off from the surface (Fig. 16).

A study of the inclusions derived from the ingested erythrocyte shows that there is a variable amount of membranous and granular material present. In some instances the bodies contain abundant membranes set in an electron dense matrix but few or no granules can be discerned (Fig. 18, opposite). In others both membranes and granules are easily seen (Fig. 19, overleaf), while many other bodies (sidero- somes) contain many electron opaque granules but $\frac{7}{\mathrm{O}}$ few or no membranes (Fig. 20, overleaf).

It must be stressed that the changes described N above have been observed in cells indistinguishable from typical synovial cells found in the surface of the synovium. However, many phagocytic cells con- $\omega$ taining bodies derived from disintegrating erythro cytes were found in deeper layers of the synovium (Fig. 21, overleaf). Here most but not all bear a strong morphological resemblance to synovial cells. 


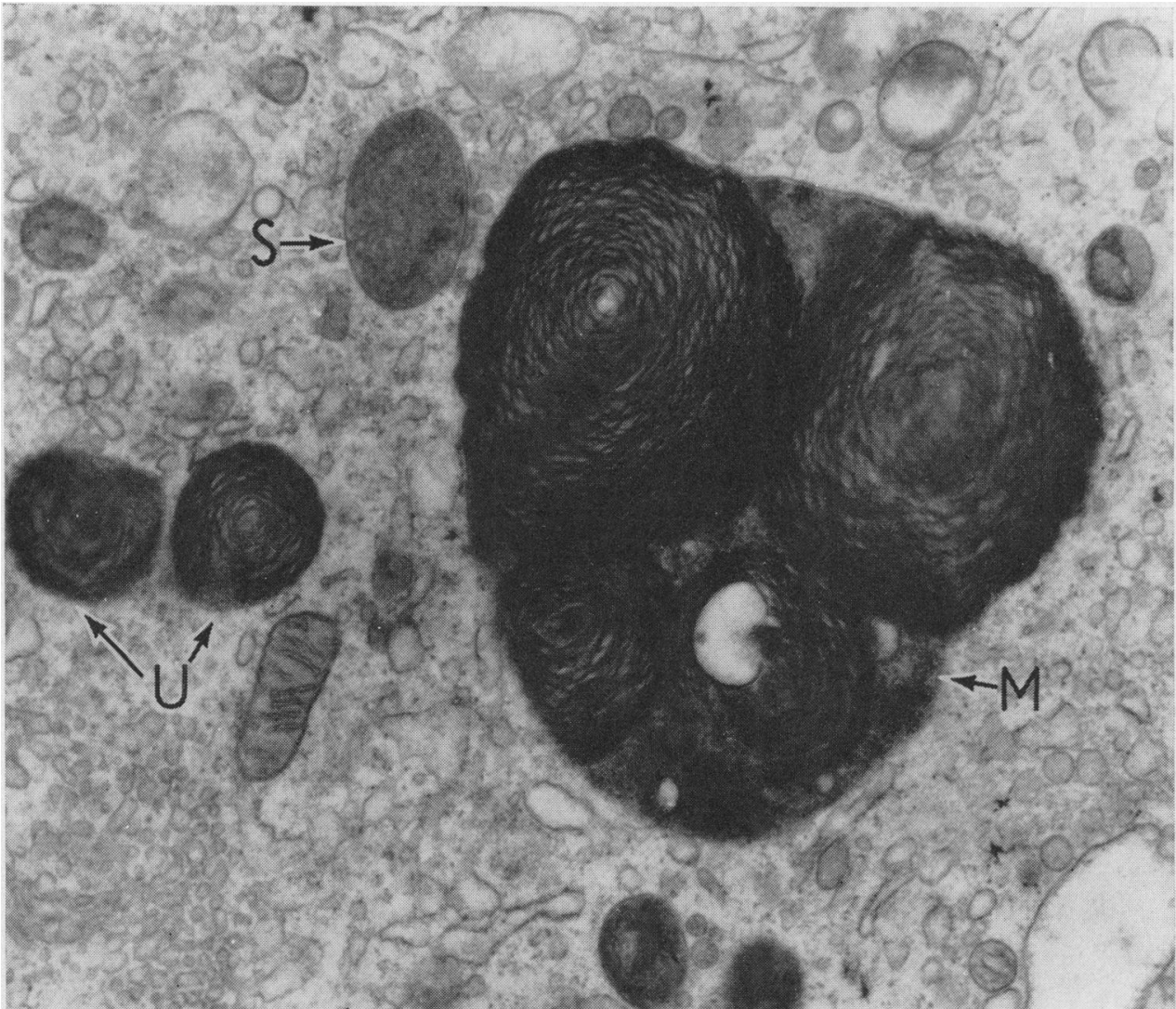

Fig. 17. - Complex body with multicentric whorled membranes (M) is seen lying in the cytoplasm of a type A synovial cell. Two smaller bodies with unicentric whorled membranes (U) and a siderosome (S) containing many electron dense granules is also seen. $\times 24,000$.

\section{Discussion}

Significance of Some Early Changes seen after Injection of Blood.-Ultrastructural studies revealed many interesting changes which occur a few hours after injection of blood. One such change is the occurrence of numerous electron dense particles in the cytoplasm of synovial cells (Fig. 9). The nature of these particles is, however, obscure. Their pattern and distribution does not suggest ribosomes or glycogen. The most plausible explanation seems to be that they might be haemosiderin granules. The fact that such granules are also found in polymorphs further supports this idea.

In view of the experimental procedures employed, it is almost certain that some lysis of erythrocytes must have occurred during the collecting and injecting of blood into the joint and also perhaps in the joint after injection. The haemoglobin thus liberated could then be degraded to produce haemosiderin which would appear in the synovial cells and poly-

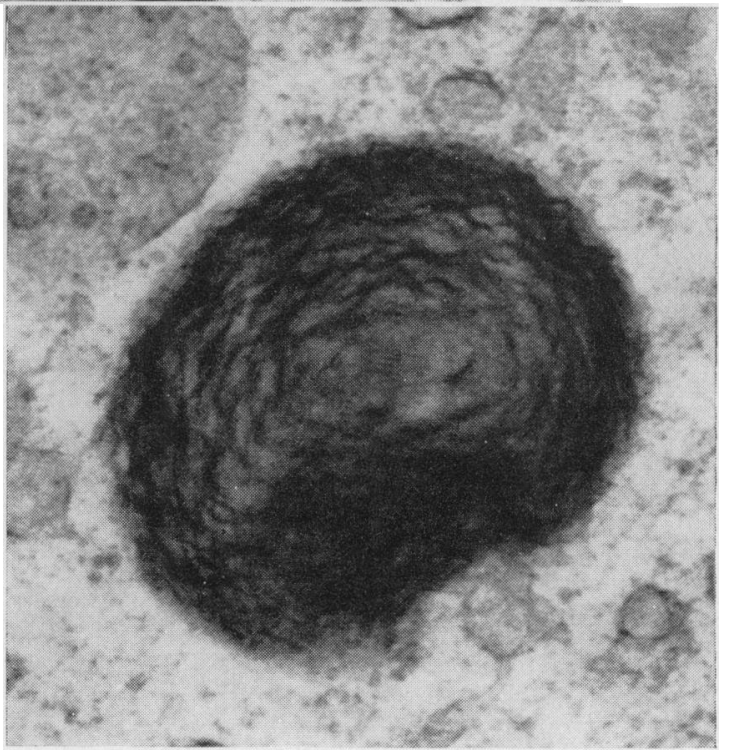

Fig. 18.-High-power view of an inclusion containing whorled membranes. $\times 70,0 \mathrm{CO}$. 


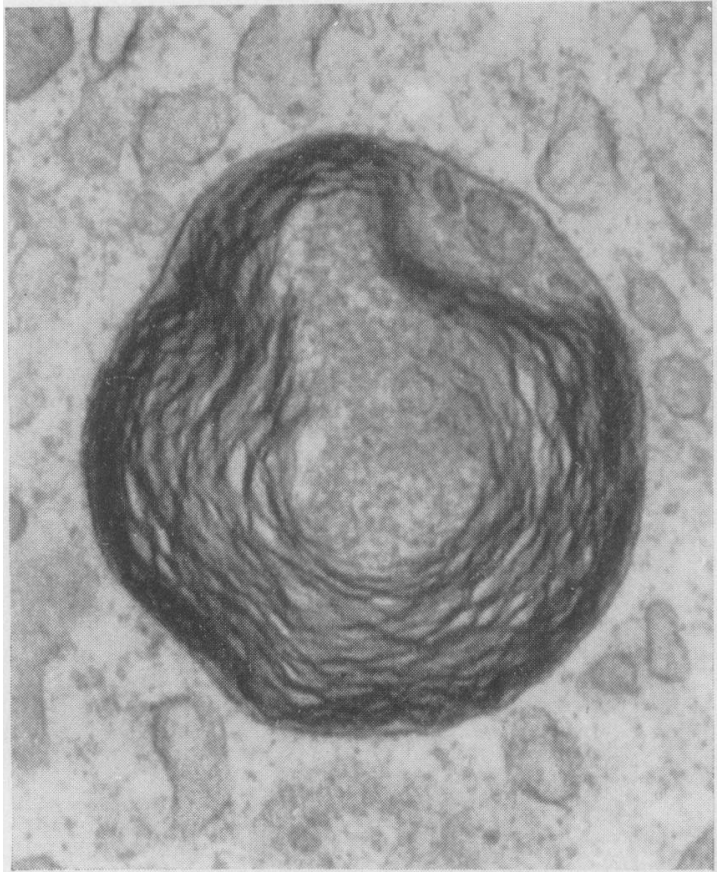

not been observed by us in normal rabbit or human $\frac{\mathscr{2}}{3}$ synovium. Since the flocculent material resembles 0 that seen on the surface of the synovium, a possible explanation would be that in both instances this $\vec{F}$ material is derived from the proteins of injected $\stackrel{\oplus}{\rightarrow}$ blood.

Perhaps it is relevant to note here that Ball, $\frac{\overline{\bar{O}}}{\bar{N}}$ Chapman, and Muirden (1964) have observed single $\frac{\text { क }}{\sigma}$ membrane bound vesicles containing iron dextran $\varnothing$ appearing in the synovial cells a few hours after $\cong$ injection of this substance in the joint.

Although the bulk of the evidence supports the $\stackrel{\circ}{-}$ above view, the possibility that these vesicles contain $\vec{\omega}$ some product produced by the synovial cells which is $\frac{}{2}$ later liberated into the joint space cannot be entirely $\frac{2}{2}$ excluded.

An early change which can be readily understood of is the occurrence of single membrane bound in- $A$ clusions containing membranous structures. It is $\mathrm{N}$ now well known (Hruban, Spargo, Swift, Wissler, 오 and Kelinfeld, 1963; Parry and Ghadially, 1965) that such inclusions are produced by a variety of $\mathcal{D}^{\infty}$ mild injuries to the cell. Such injury produces areas of focal cytoplasmic degeneration (F.C.D.) $\stackrel{\mathbb{D}}{3}$ and the membranous inclusions arise as a result of

Fig. 19.-High-power view of an inclusion containing whorled membranes and electron dense granules. $\times 70,000$.

Fig. 20.-High-power view of a siderosome, showing many electron dense granules.

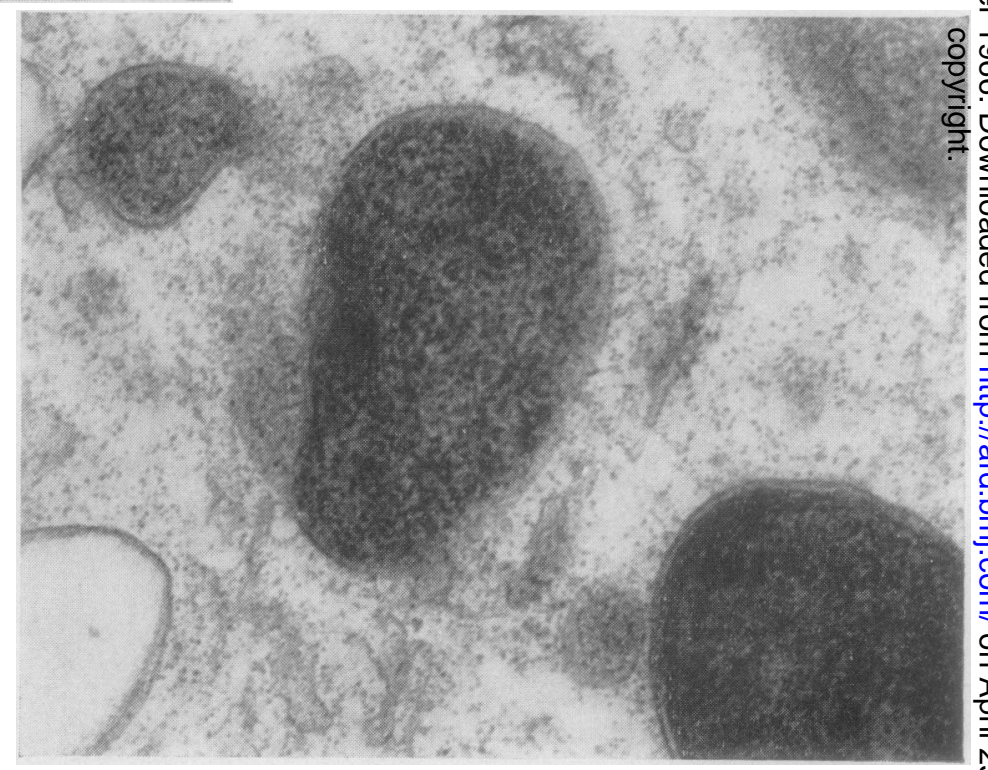

morphs. A study of the ultrastructure of synovium after injection of haemoglobin into the joint may help to clarify the nature of these electron dense particles.

Another interesting finding was the occurrence of single membrane bound inclusions containing flocculent material (Fig. 8). Such inclusions have the sequestration of mitochondria, E.R., and other organelles which then undergo enzymic digestion. $\omega$ Hence the word cytolysome is also sometimes used to describe these structures (Novikoff and Essner, 1962; Napolitano, 1963).

It is conceivable therefore that the F.C.D.s seen ? 


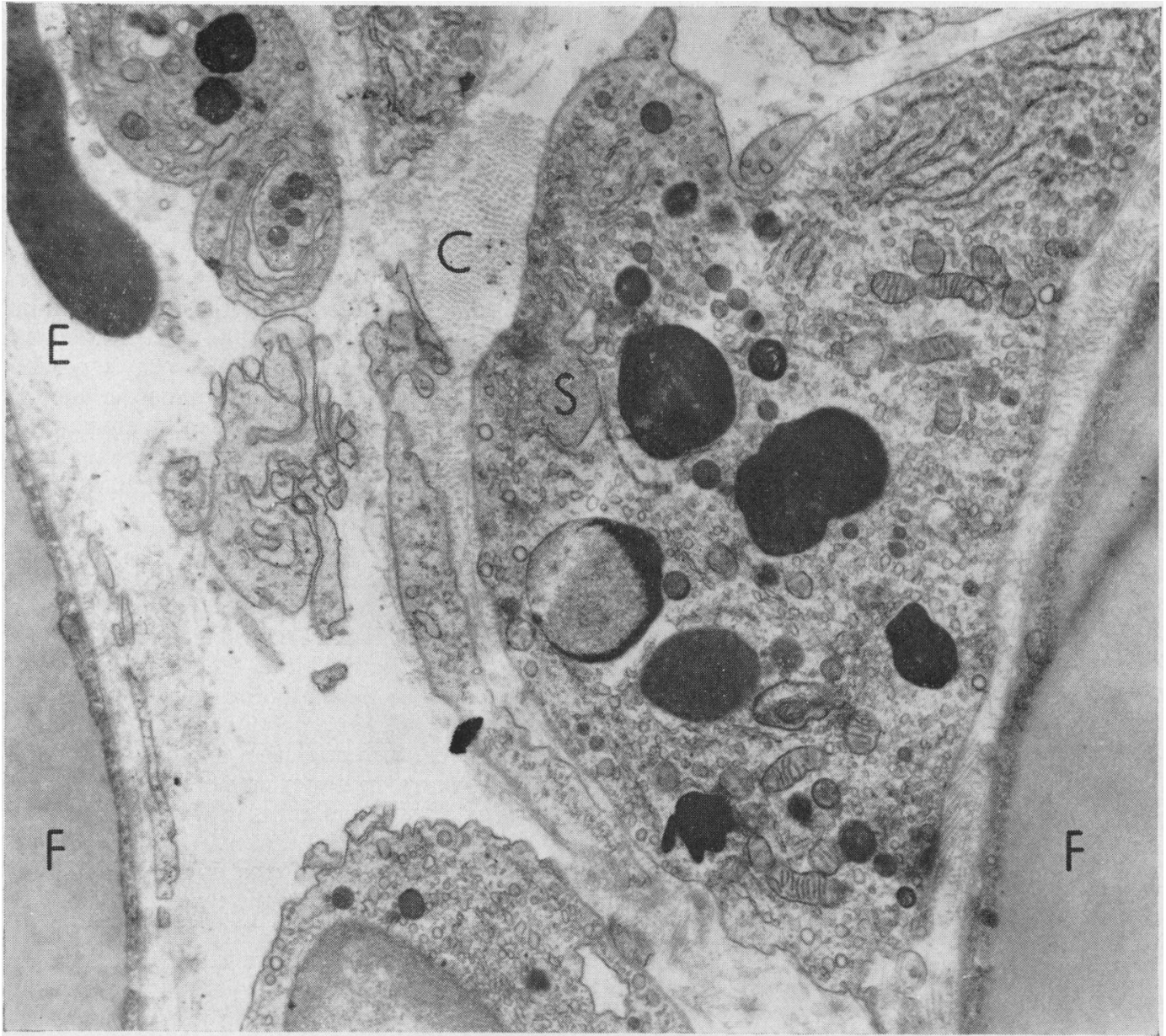

Fig. 21.-Low-power view taken at junction of synovial and subsynovial region. A phagocytic cell indistinguishable from a synovial cell (S) containing bodies derived from erythrocyte fragments is seen lying between two fat cells (F). Collagen fibres (C) and an erythrocyte (E) are seen lying in the matrix. $\quad \times 10,000$.

by us arise as a result of the injury inflicted on the synovial cells by the operative procedure and the presence of blood in the joint.

\section{Erythrophagocytosis}

Perhaps the most interesting result of our investigation is that it provides indubitable proof of erythrophagocytosis by synovial cells. That these cells are capable of phagocytosing iron dextran, thorotrast, and ferritin (Ball and others, 1964; Cochrane, Davies, and Palfrey, 1965; Muirden, 1963) has been amply demonstrated, but it is now obvious that they can also ingest much larger objects, such as erythrocytes.
Since this function is usually attributed to monocytes or histiocytes, we tried to see if the cells containing erythrocytes or their breakdown products could be distinguished from synovial cells, and whether they resembled the phagocytic cells seen elsewhere, like the monocytes of the blood or the Kupffer cells in the liver.

We found that in most instances the cells containing phagocytosed material were morphologically indistinguishable from the adjacent synovial cells. Furthermore, this phenomenon commenced at 4 hrs, a time when one does not expect a mononuclear response in an inflammatory reaction.

Though in the synovium proper there was rarely 
any doubt that the phagocytosed erythrocytes lay in the synovial cells, at times such doubts were raised regarding the nature of the phagocytic cells in the deeper subsynovial tissues.

Here again, however, our impression was that these cells though altered still bore much resemblance to synovial cells and were probably derived from them.

The net impression we have is that it is the synovial cells which phagocytose the erythrocytes and then wander downwards into the subsynovial tissues. Thus the haemosiderin-laden macrophages seen in haemarthrosis seem to be mainly of synovial origin; whether in the later stages of this process blood-borne macrophages or tissue histiocytes derived from fibroblasts assist in the process is difficult to assess. In our material there is no clearcut evidence to support such a contention.

The difficulty here is that most mesenchymal cells, like synovial cells, fibroblasts, and macrophages, have many common morphological features, and it is only in favourable instances that one can distinguish between them.

The intermutability of mesenchymal cells is now widely accepted. It seems that here we have a further example, wherein synovial cells turn into phagocytic cells when the need arises.

\section{Other Possible Ways in which Erythrocytes may escape from the Joint Space}

Key (1929) studied with the light microscope the manner in which erythrocytes escape from the joint cavity. He concluded that most of the red blood cells escaped by passing between the synovial cells, and that none were phagocytosed by them. In sections of synovium prepared from our experimental animals, we too have seen erythrocytes lying between synovial cells in the synovial matrix (Figs 2 and 21) and also in the subsynovial tissues. At times quite large numbers of such cells can be found in these situations under the light microscope.

The interpretation of this finding is however difficult, for erythrocytes lying freely in the tissues are frequently encountered by pathologists who examine biopsies of human tissues. In these cases it has long been accepted that erythrocytes seen lying free in the tissues are the result of vascular damage inevitably incurred in procuring the biopsy.

Such an explanation however is untenable in the present example, for we frequently found large numbers of erythrocytes lying in the synovium obtained from injected joints but only occasionally were a few erythrocytes seen in the synovium from control joints.

The studies of Rodnan (1960) with Chromium ${ }^{-51}$ and Iron ${ }^{-59}$ labelled red blood cells injected into the joints of rabbits also supports Key's hypothesis that a substantial number of erythrocytes escapen from the joint space into the synovial matrix. This conclusion however is based on the rapid rate at? which the radioactivity disappears from the jointo and not on autoradiographic studies which would? perhaps demonstrate this in a more convincingf manner.

However, in the light of the available evidence, ie seems to us quite feasible that a substantial number of erythrocytes escape from the joint in the manner suggested by Key, but further work is needed to establish this, and also to determine the fate of the erythrocyte after it has entered the synovium, for in 5 the experiments with chromium-labelled erythrocytio Rodnan failed to find these in the circulating bloodir

\section{Summary}

点

Blood was injected into the knee joint of the rabbit은 The manner in which it is removed was studied with the aid of the light and electron microscope. Withinfs 2 to $4 \mathrm{hrs}$ of injecting blood, electron dense particles? presumed to be haemosiderin were detected withing the synovial cells and polymorphs. It was concluded that the haemosiderin was derived from lysed? blood. Many erythrocytes were found lying fees between the synovial cells, in the synovial matres, and in the subsynovial tissues. It is therefore co ceivable that some of the injected erythrocytes escape from the joint into the synovium.

However, the most important finding was erythro phagocytosis by synovial cells. This phenomenor吕 was observed to commence within $4 \mathrm{hrs}$ of the injec tion of blood. At later stages numerous inclusions? derived from the injected erythrocytes were detected. It was found that a prerequisite to this process was fragmentation of the erythrocyte. Depending upon the size and type of fragmentation, numerous larges complex or small simple inclusions were produced

These bodies contained variable amounts of whorled membranes and electron opaque granulesô which are believed to be haemosiderin.

This work was supported by a grant from the Arthritis and Rheumatism Council. We are grateful to Mr. I. Vardey, Miss Ann Malone, Mr. R. Loomes and Miss Elizabeth Parry for their technical assistance.

\section{REFERENCES}

Ball, J., Chapman, J. A and Muirden, K D. (1964) J. Cell Biol., 22, 351.

Cochrane, W., Davies, D. V., and Palfrey, A. J. (1965). Ann. rheum. Dis., 24, 2.

Collins, D. H. (1951). J. Bone Jt Surg., 33B, 436.

.


Coulter, W. H. (1962). Arthr. and Rheum., 5, 70.

De Palma, A. F., and Cotler, J. M. (1956). Arch. Surg., 72, 247.

Ghadially, F. N., and Roy, S. (1966). Ann. rheum. Dis., $25,318$.

Ghormley, R. K., and Clegg, R. S. (1948). J. Bone Jt Surg., 30A, 589.

Glauert, A. M. (1961). In "Techniques for Electron Microscopy", ed. D. Kay., pp. 179-181. Blackwell, Oxford.

Hruban, Z., Spargo, B., Swift, H., Wissler, R. W., and Kleinfeld, R. G. (1963). Amer. J. Path., 42, 657.

Key, J. A. (1929). J. Bone Jt Surg., 11, 705.

- (1932). Ann. Surg., 95, 198.

Muirden, K. D. (1963). Arthr. and Rheum., 6, 289 (Abstract).

Napolitano, L. (1963). J. Cell Biol., 19, 478.

Novikoff, A. B., and Essner, E. (1962). Ibid., 15, 140.

Palade, G. E. (1952). J. exp. Med., 95, 285.

Parry, E. W., and Ghadially, F. N. (1965). Cancer, 18, 1026.

Reynolds, E. S. (1963). J. Cell. Biol., 17, 208.

Rodnan, G. P. (1960). Arthr. and Rheum., 3, 195.

—-, Brower, T. D., Hellstrom, H. R., Didisheim, P., and Lewis, J. H. (1959). Ibid. 2, 152.

Roy, S., Ghadially, F. N., and Crane, W. A. J. (1966). Ann. rheum. Dis., 25, 259.

\section{La pathologie de l'hémarthrose expérimentale}

\section{RÉSUMÉ}

On injecta du sang dans l'articulation du genou de lapin et on étudia à l'aide de microscopes électronique et lumineux son mode d'élimination. A bout de 2 à 4 heures dès l'injection de sang on décéla des particules denses électroniquement, probablement d'hémosidérine, dans les cellules synoviales et polymorphes. On conclut que l'hémosidérine provenait du sang lysé. On trouva beaucoup d'érythrocytes libres entre les cellules synoviales, dans la matrice synoviale et dans les tissus sous- synoviaux. Il est donc concevable que certains érythrocytes injectés s'échappent de l'articulation dans la synoviale.

Toutefois, la trouvaille la plus importante fut l'érythrophagocytose par les cellules synoviales. On observa le commencement de ce phénomène avant que 4 heures se soient écoulées depuis l'injection du sang. Plus tard on décéla de nombreuses inclusions dérivées des érythrocytes injectés. On trouva qu'une condition préalable de ce processus fut la fragmentation de l'érythrocyte. Selon les dimensions et le type des fragments, se produisirent des inclusions volumineuses et complexes ou petites et simples.

Ces corps contenaient en quantités variables des membranes verticillées et des granules électroniquement opaques et on pense qu'il s'agissait ici d'hémosidérine.

\section{La patología de la hemartrosis experimental}

\section{Sumario}

Se inyectó sangre en la articulación de la rodilla de conejo y se estudió con microscopios luminoso y electrónico el modo de su desintegración. A cabo de 2 a 4 horas desde la inyección de sangre se observaron partículas electrónicamente densas, presumiblemente de hemosiderina, en las células sinoviales y polimorfas. Se concluye que la hemosiderina fué el producto de hemólisis. Se encontraron muchos eritrocitos libres entre las células sinoviales, en la matriz sinovial y en los tejidos sub-sinoviales. Es, pués, concebible que algunos eritrocitos inyectados se escapan de la articulación a la sinovia.

Sin embargo, el hallazgo más importante fué lå eritrofagocitosis por las células sinoviales. El comienzo de este fenómeno se pudo observar dentro de las cuatrohoras de la inyección de sangre. Más tarde se vieron numerosas inclusiones derivadas de los eritrocitos inyectados. Se vió que el requisito necesario de este proceso fué la fragmentación del eritrocito. Según el tamaño y el tipo de los fragmentos, se produjeron inclusiones voluminosas y complejas o pequeñas y sencillas.

Estos cuerpos contuvieron en cantidades variables membranas verticiladas y granulos electrónicamente opacos presumiblemente de hemosiderina. 